\title{
The Dismemberment of Orpheus: Mythic Elements in Shakespeare's Romances
}

\section{Citation}

Armitage, David. 1987. The dismemberment of Orpheus: Mythic elements in Shakespeare's romances. Shakespeare Survey 39: 123-133.

\section{Published Version}

http://dx.doi.org/10.1017/CCOL0521327571.010

\section{Permanent link}

http://nrs.harvard.edu/urn-3:HUL.InstRepos:3415494

\section{Terms of Use}

This article was downloaded from Harvard University's DASH repository, and is made available under the terms and conditions applicable to Other Posted Material, as set forth at http:// nrs.harvard.edu/urn-3:HUL.InstRepos:dash.current.terms-of-use\#LAA

\section{Share Your Story}

The Harvard community has made this article openly available.

Please share how this access benefits you. Submit a story.

Accessibility 


\section{THE DISMEMBERMENT OF ORPHEUS: MYTHIC ELEMENTS IN SHAKESPEARE'S ROMANCES}

DAVID ARMITAGE

'As the soule of Euphorbus was thought to live in Pythagoras: so the sweete wittie soule of Ovid lives in mellifluous and hony-tonged Shakespeare, witnes his Venus and Adonis, his Lucrece, his sugred Sonnets among his private friends, \&c.' And so may the soul of Francis Meres be thought to live in critics who examine Shakespeare's debt to his favourite poet; since Ovid's influence is found largely in the early work it is, by implication, a youthful phase, which Shakespeare grew out of. Yet, as Ovid acknowledged through Pythagoras, 'All things doo chaunge. But nothing sure dooth perrish. This same spright/ ... never perrisheth nor never perrish can.' 2 Just so did the soul of Ovid live in Shakespeare throughout his career, to find its final expression in the four late romances. '[T] he most resonant echo of Ovid in the corpus ${ }^{3}$ occurs not in one of the works noted by Meres, but in The Tempest (as Prospero's invocation, 'Ye elves of hills, brooks, standing lakes and groves' (5.1.33-50), adapts the Latin original and Arthur Golding's translation of Medea's speech in Metamorphoses, 7. 197-209 (Golding, 11.265-77)), while it is in Cymbeline (2.2) that a copy of the Metamorphoses makes its second appearance in Shakespeare's works. Just as the book which Lavinia 'tosseth so' in Titus Andronicus (4.I.4I) is an index of a major influence on the play, so does Imogen's bedside reading show that Ovid was much in Shakespeare's mind as he was engaged in a later, and very different, Ovidian phase.
Shakespeare's changing attitude towards his most important classical influence, as well as his developing use of myth, can be suggestively illustrated by his allusions to the story of Orpheus, which he took from Ovid, and supplemented with common interpretations and personal associations. Also, as a myth whose most striking motif is dismemberment, Orpheus may provide an image for the breaking and scattering of mythic elements in the romances, most potently from the Orpheus story itself. Northrop Frye is correct when he decides that 'Orpheus is the hero of all four romances', ${ }^{4}$ but by failing to substantiate this characteristic perception by referring to Shakespeare's more abiding hero, he does not realize the full force of his speculation.

The Orpheus who haunts the romances is a composite figure, a cluster of associations which can be seen accumulating across Shakespeare's work. Two of the earliest references are symptomatic of Shakespeare's youthful attachment to Ovid as a stylistic master, as the

1 Francis Meres, Palladis Tamia, Wits Treasury (London, I 598), pp. $28 \mathrm{I}-2$.

2 W. H. D. Rouse, ed., Shakespeare's Ovid, Being Arthur Golding's Translation of the Metamorphoses (London, 1904, rep. 1961 ), bk. I5, pp. I83, I87; all references to Golding are to this edition.

${ }^{3}$ Frank Kermode, ed., The Tempest (London, 1958), p. 147. All quotations from Shakespeare are taken from editions in the New Arden Shakespeare (London, I95 I-82), unless otherwise noted.

4 A Natural Perspective (New York, 1965), p. 147. 
singer appears twice in passages of elaborate Ovidian conceit relating to rape:

He would have dropp'd his knife, and fell asleep,

As Cerberus at the Thracian poet's feet.

(Titus Andronicus, 2.4.50-1)

and

So his unhallowed haste her words delays,

And moody Pluto winks while Orpheus plays.

(Lucrece, 552-3)

Both allusions image the forestalling of a brutal assault by the sweetness of the victim's voice (though in Titus Andronicus the reference is cruelly ironic, since Lavinia has already been raped, and her tongue cut out), thus associating Orpheus with the calming of violent barbarism. The myth may be apt for the Roman setting of the works, but it is used decoratively - in contrast to the story of Philomel, for example, which has important thematic and structural force throughout Titus Andronicus. Just as decorative in its place is the striking image in The Two Gentlemen of Verona:

For Orpheus' lute was strung with poets' sinews

Whose golden touch could soften steel and stones,

Make tigers tame, and huge leviathans

Forsake unsounded deeps, to dance on sands.

(3.2.77-80)

However, even when the conscious exaggeration of the passage, and its dramatic setting, are taken into account, Shakespeare may be seen to use Orpheus as symbolic of the poet's power to move his audience, in an early moment of poetic self-awareness. The lines are spoken by an exemplary shape-shifter, Proteus, yet this does not guarantee that Ovid is the sole inspiration behind the image, since the Virgilian account of Orpheus (in Georgics, $4.457-527$ ) is narrated by the sea-god himself, who also mentions Orpheus' calming effect on tigers (Georgics, 5.510). In the absence of other reliable allusions to Virgil's pastoral poetry, ${ }^{5}$ the connections between the Georgics and The
Two Gentlemen of Verona are more probably coincidental than significant. Nevertheless, the associations made here with art, dismemberment ('strung with poets' sinews'), calmed ferocity, and, most characteristically, the depths of the sea, ${ }^{6}$ are to become more fertile as Shakespeare recalls them in the romances.

In Ovid's version, the story of Orpheus divides into three main scenes: his descent into Hades to rescue Eurydice; the power of his music over nature; and his death at the hands of the Maenads. Once Shakespeare has alluded to Orpheus' descent (in Titus Andronicus and Lucrece), and the potency of his music (in The Two Gentlemen of Verona), it only remains for him to conclude with his death. This he does in the play which is his most artfully Ovidian, yet also the one in which he first seems to question his enthusiasm for Ovid, A Midsummer Night's Dream. One of the entertainments proposed to Theseus by Philostrate is

The riot of the tipsy Bacchanals,

Tearing the Thracian singer in their rage.

(5. I. 48-9)

Theseus rejects this, and chooses instead

A tedious brief scene of young Pyramus

And his love Thisbe, very tragical mirth

in which Shakespeare satirizes Golding's verse and vocabulary, along with that of other minor contemporaries. He will continue to rely upon Golding as a source of ideas, phrases, and stories (not least in the romances), but his burlesque shows that affectionate scepticism has replaced uncritical passion as his dominant attitude towards the translator.

But Shakespeare abandons neither Ovid nor

5 For doubts about Shakespeare's knowledge of Virgilian pastoral, see T.W. Baldwin, William Shakspere's Small Latine and Lesse Greeke (2 vols., Urbana, 1944), vol. 2 , p. 464.

6 Images of unfathomed depths have been used by $\mathrm{K}$. Wentersdorf as a positive test of Shakespearian authorship, in 'The Authenticity of The Taming of the Shrew', Shakespeare Quarterly, S (1954), 25-6. 
Orpheus. His last allusion to the singer, before his final plays, may seem predictable, but only because it is so naturally integrated in its context. As part of his serenade on music to Jessica, Lorenzo details the power of music over wild animals; the exemplary mythological association then arises:

therefore the poet

Did feign that Orpheus drew trees, stones, and floods,

Since naught so stockish, hard, and full of rage, But music for the time doth change his nature.

(The Merchant of Venice, 5.I.79-82)

If the acknowledgement of 'the poet' is not merely conventional, Shakespeare almost certainly means Ovid here, since he is the only poet dignified by such particularity in his work (as in Titus Andronicus, 4. I.57, 'Pattern'd by that the poet here describes'). However, if this is so, he misrecalls the Metamorphoses, since Ovid's Orpheus drew only trees and stones, not 'floods'. The additional waters may come from the prefatory 'Epistle' to Golding's translation:

So Orphey in the tenth booke is reported too delight

The savage beasts, and for too hold the fleeting birds from flyght,

Too move the senselesse stones, and stay swift rivers, and too make

The trees to follow after him and for his musick sake

Too yeelde him shadowe where he went. By which is signifyde

That in his doctrine such a force and sweetenesse was implyde,

That such as were most wyld, stowre, feerce, hard, witlesse, rude, and bent

Ageinst good order, were by him perswaded too relent. ('Epistle', 517-24; my emphasis)

Wherever the addition came from, it is important in renewing the association in Shakespeare's mind between Orpheus' music and 'floods' - or 'unsounded deeps' - seen in The Two Gentlemen of Verona, and which is pregnant with meaning for the romances.
Lorenzo's speech also shows Shakespeare allegorizing the myth for the first time, as he glosses it with a conventional interpretation similar to Golding's. Yet he did not need Golding as a direct or sole source for this allegorization. It seems likely that he used an annotated Ovid at school, and had access to widely used lexicons, ${ }^{7}$ but even so, at a time when myth was a major item of intellectual currency, such interpretations were commonplace. For example, when Shakespeare alluded to Actaeon in the opening scene of Twelfth Night - 'That instant was I turn'd into a hart, / And my desires, like fell and cruel hounds, / E'er since pursue me' (I.I.2I-3) - he did not need to name the huntsman, since he could assume that the allusion would be recognizable, and that his audience would know the usual interpretation of the episode as an emotional turmoil.

The variety of allusions to Orpheus in Shakespeare's earlier work shows that he had a detailed knowledge of the myth, as found in Ovid and Golding, and of the common interpretations of it. These details are enriched by personal associations, and all return in those plays where mythologizing is combined with mythopoeia - the romances. Myth has become more integral to the poetic fabric of the plays, developing from decorative spangling in the early work to concealed fertile allusion (such as Actaeon in Twelfth Night). In the romances, the direct references are more pointed and resonant, the indirect ones more elusive and fruitful. Partly because of this skilful absorption of mythic elements, the romances seem to partake of the nature of myth, as has often been observed. G. Wilson Knight, for example, said of Shakespeare in this late phase, 'the author is moved by vision, not fancy; is creating not merely entertainment, but myth in the Plato-

7 See e.g. D. T. Starnes and E. W. Talbert, Classical Myth and Legend in Renaissance Dictionaries (North Carolina, 1955), pp. III-34; R.D. Drexler, 'Ovid and The Tempest', Notes and Queries, 28 (1981), p. 145. 
nic sense'. ${ }^{8}$ It is not necessary to agree with the assumptions of his criticism, or to examine too closely the connotations of 'in the Platonic sense', to concur with Wilson Knight in finding these plays mythic (in atmosphere, resonance, and indeterminancy, if not in intention); a more accurate, and suggestive, description of them might be 'myths in the Ovidian sense'.

In the Metamorphoses, stories are linked by a variety of factitious connections, but the thematic ties are vital, as sequences are established, and significances sprung across discrete narratives. As John Dean suggests, Shakespeare's 'use of the Metamorphoses may have contributed directly to his sense of romance structuring, '9 and in the light of Ovid's practice the four late romances could be seen as a cycle, analogous to a section of the Metamorphoses. Book 10 and the opening of Book II, for instance, are framed by the story of Orpheus, who is the narrator of Book Io, choosing the stories therein to reflect his mood or activities - stories of unhappy love, such as Venus and Adonis (which we can be sure Shakespeare knew), or the tale of an animative artist, Pygmalion. Shakespeare is the framing Orpheus of the romances - though his motives for writing them may be beyond conjecture and he creates a series which forms the most integrated group of plays in his output, ${ }^{10}$ save perhaps his carlier historical cycles. They may differ in style and setting, but, like Ovid's narratives, they are linked by a common atmosphere, recurrent motifs, and parallel thematic movements.

Ovid is often blamed for not being Virgil, particularly when their versions of the Orpheus myth are compared. ${ }^{11}$ As can be seen from such a comparison, Ovid's ethos is that of romance, not tragedy. Virgil's Orpheus is the victim of tragic 'furor' (Georgics, 4. 495), who offends against the inflexible divine order, loses his wife, and descends into inconsolable grief, only to be torn to pieces by the Maenads. Virgil emphasizes fate (Eurydice is doomed, 'moritura puella' (458)), high emotions, the seriousness of suffering, and obeisance to a vast, over-arching order; his Orpheus is demi-god, rather than semi-man. Ovid dissolves his predecessor's high seriousness and challenges the Virgilian gravitas, a style expressive of a world view comprehending tragic solemnity and punitive hierarchy. Ovid's outlook, as well as his subject matter, is metamorphic. He emphasizes regeneration and transfiguration; achieved possibility and relieved suffering; capricious gods and indistinct causality. Like Shakespeare in his late plays, Ovid goes beyond irredeemable tragedy to romance, which is always provisional in its catastrophes and promises reunion after division, life after death, and joy after disaster. 'The thrust of romance, as a genre, is the redemption of a world full of misfortune, a blossoming of new life out of loss and death, and an affirmation of the ultimate harmony that may follow, even proceed from, tragedy.'12 Ovidian metamorphoses, and Shakespearian romances, are amply comprehended by such a definition. Ovid's sympathetic nature, harmonizing music, and patterns of transfiguration in his telling of the story of Orpheus are such stuff as romance - or a Shakespearian romance - is made on.

8 'Myth and Miracle' in The Crown of Life (London, I965), p. 15.

9 Restless Wanderers: Shakespeare and the Pattern of Romance (Salzburg, 1979), p. 199.

10 Even if they are not a chronological group; for evidence that Coriolanus follows Pericles, see Gary Taylor, 'The Shakespeare Canon: New Evidence for Chronology and Authorship' (forthcoming). I am grateful to $\mathrm{Mr}$ Taylor for giving me details of his conclusions.

11 E.g. W. S. Anderson, 'The Orpheus of Virgil and Ovid: flebile nescio quid' in Orpheus: the Metamorphoses of a Myth, ed. John Warden (Toronto, I982), pp. 25-50; for a more sympathetic account of Ovid's version, to which I am indebted, see Charles Segal, 'Ovid's Orpheus and Augustan Ideology', Transactions of the American Philological Association, I03 (1972), 473-94.

12 Peggy Ann Knapp, 'The Orphic Vision of Pericles', Texas Studies in Literature and Language, is (1974), p. 619. 
While the generic similarities between the Ovidian narrative and the romances can be felt, the precise influence of the Orpheus episode can be detailed in the plays. In Cymbeline, Iachimo muses on

The cloyed will-

That satiate yet unsatisfied desire, that tub Both fill'd and running.

(I. 7.47-9)

Although the Arden editor is loath to see this as a definite allusion to the Danaides (who had to fill a bottomless vessel eternally as a punishment for killing their husbands), he refers to Marston's The Fawn - where the myth is mentioned twice, the vessel being called a 'tub' both times - and to Horace, Odes, 3.II.26, as the ultimate source. ${ }^{13}$ Yet there is no need to invoke either Marston or Horace here, since Golding supplies both the allusion and the word 'tubbes' (which Shakespeare, a magpie for distinctive words and phrases, could have picked up). One of the eternal punishments halted by Orpheus' music on his descent to the underworld is translated thus:

And Danaus daughters ceast too fill theyr tubbes that have no brink.

The homely monosyllable 'tubbes' (translating 'urnis') is characteristic of Golding, who often takes Ovid's realism to excess. The ethical interpretation that supports Iachimo's image is a conventional one: Georgius Sabinus, for example, glosses the lines 'urnisque vacarunt/ Belides' (Metamorphoses, 10.43-4) with, among other information, this allegorization:

His urnis \& huic dolio Plato in Gorgia assimilat animum incontinentem, qui effusis in omni intemperentia libidinibus agitatur. ${ }^{14}$

(In the Gorgias, Plato compares these urns and this jar to an insatiable disposition, which is aroused by desires that find their outlet in every excess.)

Similar ideas of sated insatiability are, of course, found elsewhere in Shakespeare, but the confluence of Golding's 'tubbe(s)' and the ethical slant suggests that Shakespeare was thinking of the Danaides, and that he had recently re-read Golding's translation of the Orpheus episode.

Evidence that he had re-read not only Golding's version but also the original Latin comes from the additions to his - and our - vocabulary in the romances. In Metamorphoses, 10.64, at the moment of losing Eurydice for the second time,

stupuit gemina nece coniugis Orpheus

(This double dying of his wyfe set Orphye in a stound.)

(Golding, 10.69)

This typically Ovidian conceit 'gemina nece' (compare 'iterum moriens' (I0.69)) is important for The Winter's Tale, as will be shown, and 'stupuit' seems to have excited resonances. It is solely in Cymbeline and The Winter's Tale that Shakespeare uses words with the Latin root 'stupere' - 'stupefy', 'stupefied', and 'stupid':

Those she has

Will stupefy and dull the sense awhile

(Cymbeline, 1.6.36-7)

which if you, or stupefied,

Or seeming so, in skill, cannot, or will not

Relish a truth

(The Winter's Tale, 2.2.165-7)

and

is he not stupid

With age and alt'ring rheums?

(The Winter's Tale, 4.4.399-400)

'Stupid', in The Winter's Tale (4.4), is cited by $O E D$ as its first use in the sense 'Having one's faculties deadened or dulled; in a state of stupor; stupefied, stunned', ${ }^{15}$ while 'stupe-

13 J. M. Nosworthy, ed., Cymbeline (London, 1969), n. to I. 7.48-9.

14 Metamorphoses seu Fabulae Poeticae (Frankfurt, 1589), sig. $\mathrm{Y}_{I^{v}}$ (my translation); cf. e.g. Jacobus Pontanus, Metamorphoseon (Antwerp, 1618), p. 393 (quoting Lucretius, De Rerum Natura, III, $1003-10)$; Geffrey Whitney, A Choice of Emblemes (Leyden, 1586), p. 12 ('Frustra').

15 OED, s.v. stupid, adj. A, I. 
fied', in The Winter's Tale (2.1), as a participial adjective, antedates $O E D$ 's first citation (from John Taylor, the Water Poet, in . 1639) by twenty-eight years ${ }^{16}$ (assuming the play was written in $16 \mathrm{I} I$ ). Both 'stupid' and 'stupefy' had been in the language, with other senses, and used in different ways, before Shakespeare wrote the romances, but that he should so innovatively and sparingly re-use them is perhaps attributable to the prominence of the root at the crucial moment in the Ovidian narrative.

As well as these suggestive, though previously unnoticed, influences from Metamorphoses, Io, some larger, better attested borrowings from Book I I deserve notice. The best known occurs in The Winter's Tale, where Shakespeare snaps up the name and thievish disposition from the son whom 'Chyone' bears to Mercury,

hyght Awtolychus, who provde a wyly pye,

And such a fellow as in theft and filching had no peere.

(Golding, 11.360-1)

While here Book II helps Shakespeare's naming and characterization, elsewhere it affects his plot and imagery, as he recalls the story of Ceyx and Alcyone. Steevens noted that Imogen and Pisanio, when discussing Posthumus' departure in Cymbeline (1.4.8-22), echo Ovid's moving description of Ceyx's ship dwindling into the distance as Ceyx looks on; Shakespeare had also remembered this passage in an acknowledgedly Ovidian work, Venus and Adonis, and had conflated it with an important image from later in Ovid's version which he returned to repeatedly in the romances (none of these reminiscences has, I think, been remarked before):

as one on shore

Gazing upon a late embarked friend,

Till the wild waves will have him seen no more,

Whose ridges with the meeting clouds contend

(Venus and Adonis, 817-20)
The image in line 820 comes from Ovid's extended account of a storm and shipwreck, which also seems to have provided material for the sea-plays, Pericles and The Tempest, and for The Winter's Tale, a coastal work:

The surges mounting up aloft did seeme to mate the skye,

And with theyr sprinckling for too wet the clowdes that hang on hye.

(Golding, II.573-4)

One of Shakespeare's favourite images in storm passages in the romances is this Ovidian one of the coalescence of sea and sky:

the brine and cloudy billow kiss the moon

(Pericles, 3.1.45-6)

But I am not to say it is a sea, for it is now the sky; between the firmament and it you cannot thrust a bodkin's point

(The Winter's Tale, 3.3.83-6)

and

the sea mounting to th' welkin's cheek.

(The Tempest, 1.2.4)

These unnoticed recollections reveal the persistence of certain parts of the Metamorphoses throughout Shakespeare's career, from his earliest phase of Ovidianism to his last, as do the allusions to Orpheus. Also like the Orpheus story, the narrative of Ceyx and Alcyone is an Ovidian romance (as Chaucer may have recognized when he called it 'A romaunce' in The Book of the Duchess, 48), and so may have had a less tangible influence on the nature of Shakespeare's romances; drowned Ceyx and grief-stricken Alcyone are reunited after death, as are Orpheus and Eurydice, when both are metamorphosed into birds, tragedy ${ }^{17}$ thereby being redeemed to become comedy.

As here an episode with a strong marine element influences the romances - in detail and, possibly, in spirit - so the more personal

16 Ibid., s.v. stupefied, ppl. a.

17 For Ceyx and Alcyone as tragedy, see Julius Caesar Scaliger, Poetices libri septem (Heidelberg, 1617), III, xcri. 
association between Orpheus and the depths of the sea returns. In these plays, the sea becomes an analogue to Hades in the Orpheus myth. His descent is a purgatorial journey, a defeat of death, and a successful challenge by the apostle of harmony to the forces of disharmony and destruction. While Orpheus returns from the depths of the underworld, Thaisa, Ferdinand, and Alonso (the first in fact, the other two in fancy) return from the sea. When Pericles casts Thaisa overboard, he regrets that he

\section{straight}

Must cast thee, scarcely coffin'd, in the ooze;

Where, for a monument upon thy bones,

And e'er-remaining lamps, the belching whale

And humming water must o'erwhelm thy corpse,

Lying with simple shells. (Pericles, 3.I.59-64)

In Ariel's song, 'Full fadom five' (The Tempest, I.2.399-405), the sea is seen as the agent of Alonso's metamorphosis; though in the song the sea-change is physical, his metaphorical immersion does seem, by the end of the play, to have exercised a purgatorial change in his attitude towards Prospero. Alonso himself expresses the Orphic association of music and the sea-bed:

Methought the billows spoke, and told me of it;

The winds did sing it to me; and the thunder,

That deep and dreadful organ-pipe, pronounc'd

The name of Prosper: it did bass my trespass.

Therefor my son i' th' ooze is bedded; and

I'll seek him deeper than e'er plummet sounded,

And with him there lie mudded. $\quad(3.3 .96-102)$

This imaginative connection between music ('sing', 'organ-pipe', 'bass') and the depths of the ocean is characteristically Shakespearian, and returns in Prospero's valedictory invocation (whose rich Ovidian echoes were noted above), where the words formerly given to Alonso are re-used: and, when I have requir'd Some heavenly music, - which even now I do, To work mine end upon their senses, that This airy charm is for, I'll break my staff, Bury it certain fadoms in the earth, And deeper than did ever plummet sound I'll drown my book. [Solemn music] (5.I.5I-7).

Orpheus is a shadowy presence in this passage by virtue of an association within Shakespeare's mind. However, his metaphorical tutelage extends over all the romances in one of their more noticeable (and noticed) features - music. The musical richness of these plays far exceeds anything in Shakespeare's previous work, and may partly be explained by the King's Men's acquisition of the Blackfriars - whose musicians had a considerable reputation - in 1608 . The virtuosity of the Blackfriars musicians certainly presented the playwright with greater opportunities than before, but this alone cannot account for the peculiar potency and privilege granted to music in the romances. Shakespeare had presented it as a regenerative force in the Quarto version of King Lear, when the Doctor asks, over the sleeping Lear, 'Please you draw neere, louder the musicke there' ${ }^{\prime 18}$ (the character and his line are omitted in the Folio), but it is in Pericles - another play presumed to date from before the acquisition of the Blackfriars - that he dramatizes its power fully; when Cerimon revives Thaisa, music is one of his major restorative agencies:

The still and woeful music that we have, Cause it to sound, beseech you. [Music] The viol once more; how thou stirr'st, thou block! The music there!

[Music] (3.2.90-3)

While here, the enlivening power of music is realized dramatically in the restoration of the mother, the restitution of the daughter finds music being used as the background to a metaphorical harmonization:

\footnotetext{
${ }^{18}$ Q1 (London, 1608), sig. $\mathrm{K}^{\mathrm{x}}(4.7 .25$ in the Arden conflation).
} 
Pericles. ... But hark, what music?

Tell Helicanus, my Marina, tell him

O'er point by point, for yet he seems to doubt,

How sure you are my daughter. [Music] But what music?

Helicanus. My lord, I hear none.

Pericles. None?

The music of the spheres! List, my Marina. L $\gamma$ simachus.

It is not good to cross him; give him way.

Pericles. Rarest sounds! Do ye not hear?

Lysimachus.

Music, my Lord? I hear. Pericles.

Most heavenly music!

(5. I.222-31)

The highest and most natural symbol of harmony, the music of the spheres, is a perfectly imagined background to such a reunion, providing an image of accord - as earlier it was the agent of it - at a crucial moment of dramatic and personal resolution.

The litcral and metaphorical capabilities of music are realized more comprehensively in The Tempest, which contains more songs than any other play by Shakespeare, and requires instrumental music as well. On 'the isle ... full of noises, / Sounds and sweet airs, that give delight, and hurt not' (3.2.133-4), the Orphic power of music as an harmonic agency is inescapable; for example, in 2. I, the courtiers are halted in their wrangling by 'Ariel ... playing solemn music' (SD, 179), while it is Ariel's redemptive 'music and song' (SD, 292) which forestall the plot against Alonso, and restore political harmony. Ferdinand provides a more precisely Orphic image, when he describes how

This music crept by me upon the waters, Allaying both their fury and my passion

(1.2.394-5)

combining the emotionally ameliorative power of music (exemplified by Orpheus in The Merchant of Venice) with its ability to calm the sea (which Shakespeare associated with Orpheus in The Two Gentlemen of Verona). Pericles and The Tempest allegorize and image the force of music as they enact it - and as they realize some of the implications of the Orpheus myth.

Such implications are dramatized most powerfully in the final scene of The Winter's Tale, where there is a scattering of dismembered elements from the myth. A suggestively Ovidian metamorphosis marks the presence of Orpheus in the statue scene (5.3), in which Shakespeare, like Ovid, combines the myths of Orpheus and Pygmalion. The parallel between Hermione and Galatea has often been drawn: ${ }^{19}$ both are statues transformed into living women in return for their lover's patient devotion. Yet in Metamorphoses, Io, it is Orpheus who tells the story of Pygmalion and Galatea as a hopeful expression of the generative power of the artist and the hard-won rewards of love; Pygmalion's art can give life to inanimate material, like Orpheus', but it exacts no cost so painful as the loss of Eurydice. Ovid's framing of the two narratives is designed to point up the thematic connections between them, and it is these that Shakespeare dramatizes in this climactic scene. As the 'statue' is brought to life, the instrument of metamorphosis called for by Paulina recalls Orpheus' lute in The Two Gentlemen of Verona, 'Whose golden touch could soften steel and stones' (3.2.78; my emphasis):

Music, awake her; strike!

'Tis time; descend; be stone no more.

$(5.3 .98-9)$

Hermione's return to life, and the reunion of the characters, are Shakespeare's major departures from his source, Greene's Pandosto, in which the queen remains dead, and the king commits suicide. By ending with a triumph over seeming tragedy, he turns the prose romance into an Ovidian one, such as the story of Ceyx and Alcyone, or that of Orpheus and Eurydice (in which the lovers' shades are

${ }^{19}$ Most fully by A. H. R. Fairchild, Shakespeare and the Arts of Design (Missouri, 1937), pp. 71-4. 


\section{THE DISMEMBERMENT OF ORPHEUS}

happily reunited in Elysium). The play's resolution is precarious, and the tragic possibilities still latent in this closing scene are signalled by a more precise echo of the Orpheus myth. As Hermione descends, Paulina urges Leontes:

\section{Do not shun her}

Until you see her die again; for then

You kill her double.

$(5 \cdot 3 \cdot \operatorname{105}-7)$

This conceit of double dying is typically Ovidian, and, as noted above, it comes at the most poignant moment in Ovid's version of the Orpheus story ('stupuit gemina nece coniugis Orpheus' (10.64; my emphasis)). Paulina's advice is a test of Leontes' steadfastness and repentance, as Orpheus' lethal solicitude for Eurydice is inverted: Orpheus killed his wife 'double' with a loving look, while Leontes may do the same to his if he does not give her such a look.

The presence of Orpheus in the statue scene can be further illuminated by a comparison with two contemporary analogues, in Beaumont's Masque of the Inner Temple and Gray's Inn, and Campion's The Lords' Masque. In his practical essay, 'Of Masques and Triumphs', Bacon counsels:

Let Antimasques not be long; They have been commonly of Fooles, Satyres ... Cupids, Statua's Moving, and the like. ${ }^{20}$

Bacon would almost certainly have seen the 'Statua's Moving' in Beaumont and Campion's masques, since both were written for the celebrations surrounding the marriage of Princess Elizabeth in February, I6I3; he could also have seen The Winter's Tale - which may have begun the theatrical fashion for moving statues - for it, like Much Ado About Nothing, and The Tempest, was presented during the festivities by the King's Men. Orpheus is present alongside the moving statues in both of the masques. As the statues enter dancing in the Masque of the Inner Temple, Mercury observes:
See how they move, drawne by this heavenly joy,

Like the wilde trees, which follow'd Orpheus Harpe.

$(1 \mathrm{ll} \text {. } 63-4)^{21}$

The image is apt, but, like Shakespeare's early references to Orpheus, it has been applied rather than absorbed. Campion's use of Orpheus is more elaborate and explicit, as the singer is the masque's controlling figure. The most spectacular coup de théatre in the piece is the scene change which reveals 'foure Noble women-statues of silver, standing in Severall nices', ${ }^{22}$ who have been petrified by an angry Jove. When Jove's aid is solicited to reanimate the statues, the prayer is, in fact, an 'Invocation in a full Song', since Prometheus' advice has been taken:

Let Orpheus decke the Hymne, since pray we must.

The music exercises its softening power and, as Orpheus notes,

Jove is pleas'd; Statues have life and move:

Go, new-borne men and entertaine with love

These new-borne women... ... Court them faire:

When words and Musicke speak, let none despaire

Art's power, and the prospect of a loving union, are dramatically united in the transformation, as in The Winter's Tale. Yet, in the masque the effect is spectacular, rather than mysterious and climactic as in the play. While Shakespeare charges the atmosphere of the drama with an imaginative absorption of the myth, Campion loses mythic resonance and creates a lesser dramatic illusion. Nevertheless, a sensitive courtly spectator who saw the two masques - especially Campion's - and The

20 Essayes (London, I625), p. 225.

21 Ed. Fredson Bowers in The Dramatic Works in the Beaumont and Fletcher Canon (Cambridge, 1960-), vol. I.

22 Works, edited by Walter R. Davis (London, 1969; page refs. are to this edn.), p. 255. 
Winter's Tale together in 1613 must have been struck by déjà $v u$ occasioned as much by sympathetic Orphic resonances as by 'Statua's Moving'.

Shakespeare's most radical dismemberment of the myth is in Cymbeline, where, decked in a cluster of images and associations, Cloten masquerades as Orpheus. The boorish prince is the instigator of the play's most noticeable musical episode, when he uses 'Hark, hark, the lark' (2.3.19-25) as a seductive aubade to Imogen. While he is obviously inharmonious, in his illiterate speech, as in his lumpen bearing, he can understand that Imogen may be moved by the music he controls:

I am advised to give her music a mornings, they say it will penetrate. [Enter musicians.] Come on, tune: if you can penetrate her with your fingering, so: we'll try with tongue too

(2.3.11-14)

yet the crudity of the word-play belies the sweetness of the music, and renders it impotent. Later, like Orpheus, Cloten is murdered by 'mountaineers' on a wild, pastoral hill-side. If Cloten is identified with Orpheus, in Golding's baffling moralistic reading, he gets his just deserts for attempting to seduce his step-sister:

The death of Orphey sheweth Gods just vengeaunce on the vyle

And wicked sort which horribly with incest them defyle.

('Epistle', 224-5)

A more relevant allegorization of Orpheus' death is the political one supplied by George Sandys, in which the Maenads are

taken for the heady rage of mutiny and Sedition, which silence the authority of the law; and infringe that concord (the musicke of Orpheus) which had reduced wild people to civility; retuming now to their former pravity and naturall fiercenesse. ${ }^{23}$

Just as Cloten is an ironic Orpheus, so are the 'mountaineers' ironic Maenads; Guiderius and Arviragus may be living a wild existence, but they are nevertheless more civilized, and more royal, than Cloten. His death could be inter- preted as a return to harmony, as the wild man from the ruling family is killed by the resurgent representatives of natural 'civility' and the blood line.

The ironic reworking of the Orpheus myth around Cloten comes to a head in a striking, unremarked image:

\section{I have ta'en}

His head from him: I'll throw't into the creek Behind our rock, and let it to the sea, And tell the fishes he's the queen's son, Cloten

(4.2. $150-4)$

repeated in:

I have sent Cloten's clotpoll down the stream

In embassy to his mother.

(4.2.184-5)

Only the memory of Orpheus' head, floating down the river Hebrus, prophesying as it went, could have allowed this head to go 'In embassy' and to 'tell the fishes he's the queen's son, Cloten'. The source usually cited for 4.2. I50-4 (from The Mirror for Magistrates) describes dismemberment, but the head is not specifically mentioned, as Hamo relates how

In flight I taken was, and hewde in pieces small:

Which downe the cleeves they did into the waters cast. ${ }^{24}$

That the reference in $4.2 .184-5$ is immediately followed by 'Solemn music' also suggests an association between the severed head and music that may recall Orpheus' head being accompanied by his harp on its river journey.

Shakespeare finally recollects the myth in Henry VIII, in which the song 'Orpheus with his lute' (3.1.3-14) may be seen as his farewell to Orpheus - and thus, by association, to Ovid - as he moves away from the dramatic romance. Despite the teasing similarities between the lyric and an undistinguished passage in Beaumont and Fletcher's The Cap-

23 Ovid's Metamorphosis Englished (Oxford, 1632), p. 387.

24 Lily B. Campbell, ed., Parts Added to the Mirror for Magistrates (Cambridge, 1946), p. 314. 


\section{THE DISMEMBERMENT OF ORPHEUS}

$\operatorname{tain}^{25}$ there is little reason to assume that it is not by Shakespeare. The description of Orpheus' power over nature - even over 'the billows of the sea' - may not be uniquely Shakespearian (as comparison with The Captain shows), but it is characteristically so; when combined with the statement of music's power over the emotions,

In sweet music is such art,

Killing care and grief of heart

Fall asleep, or hearing die (3.I.12-14) the song provides a summary of a myth which has suffused the romances, and of its implications. Orpheus may seem to have been irreparably dismembered in these plays, but this envoi shows conclusively that Shakespeare does remember him. ${ }^{26}$

25 3. I.32-8; edited by L. A. Beaurline in The Dramatic Works..., vol. I; in both passages trees 'bow' (cf. Capt., 3.1.34-5 and HVIII, 3.1.3-5), and in both the waves of the sea have 'heads' (cf. Capt., 3.1.36-7 and HVIII, 3.I.10-11), for example.

26 I am particularly grateful to Jonathan Bate and Anne Barton for help with earlier versions of this essay. 